\section{Tussive effect of a fentanyl bolus}

Wee Thuan Phua MBBS; MMed(Anacs), Boon Teck Teh MBBS, Winston Jong MBBS FFARACS, Tat Leang Lee MBBS FFARACS MMed(Anaes), William A. Tweed MD FRCPC
The aim of this study was to investigate the incidence of pre-induction coughing, after an iv bolus of fentanyl. The siudy sample was 250 ASA physical status I-II patients, scheduled for various elective surgical procedures. The first 100 were randomly allocated to recieve $1.5 \mu \mathrm{g} \cdot \mathrm{kg}^{-1}$ fentanyl via a peripheral venous cannula (Group l), or an equivalent volume of saline (Group 2). Twenty-eight per cent of patients who received fentanyl, but none given saline, coughed within one minute $(P<0.0001)$. The second 150 patients were then randomly assigned to three equal pretreatment groups. Group 3 received $0.01 \mathrm{mg} \cdot \mathrm{kg}^{-1}$ atropine iv one minute before fentanyl. Groups 4 and 5 received $0.2 \mathrm{mg} \cdot \mathrm{kg}^{-1}$ morphine im, and $7.5 \mathrm{mg}$ midazolam po, respectively, one hour before fentanyl. Thirty per cent of patients in Group 3,6\% in Group 4, and 40\% in Group 5, had a cough response to fentanyl. Fentanyl, when given through a peripheral cannula, provoked cough in a considerable proportion of patients. This was not altered by premedication with atropine or midazolam, but was reduced after morphine $(P<0.01)$. Coughing upon induction of anaesthesia is undesirable in some patients, and stimulation of cough by fentanyl in unpremedicated patients may be of clinical importance.

Le but de cette étude était d'investiguer l'incidence de la toux pré-induction après bolus intraveineux de fentanyl. La population de l'étude était de 250 patients ASA I-II cédulés pour des procédures chirurgicales électives variées. Les premiers 100 patients furent randomisés afin de recevoir $1.5 \mu \mathrm{g} \cdot \mathrm{kg}^{-1}$ de fentanyl à travers une canule veineuse périphérique (Groupe I), ou un volume équivalent de salin (Groupe 2). Vingt-huit pour cent des patients y ont reçu du fentanyl mais aucun de ceux qui ont reçu du salin, ont toussé à l'intérieur d'une minute $(P<$ $0,0001)$. Les 150 autres patients furent ensuite randomisés en

\section{Key words}

ANALGESICS: fentanyl;

COUGH.

From the Department of Anaesthesia, National University Hospital, 5 Lower Kent Ridge Road, Singapore 0511.

Address Correspondence to: Dr. Wee Thuan Phua, Registrar, Department of Anaesthesia, National University Hospital, 5 Lower Kent Ridge Road, Singapore 0511.

Accepted for publication 22nd November, 1990. trois groupes égaux de prétraitement. Le groupe 3 a reçu 0.01 $m g \cdot \mathrm{kg}^{-1}$ d'atropine iv une minute avant le fentanyl et le groupe 4 et 5 ont reçu $0,2 \mathrm{mg} \cdot \mathrm{kg}^{-1}$ de morphine im et $7,5 \mathrm{mg}$ de midazolam po, respectivement, une heure avant le fentanyl. Trente pour cent des patients dans le Groupe 3, 6\% dans le Groupe 4, et 40\% dans. le Groupe 5, ont présenté de la toux lors de l'injéction du fentanyl. Le fentanyl, lorsqu' administré dans une canule périphérique, a provoqué de la toux chez un grand nombre de patients. Ceci ne fut pas altéré par la prémédication avec l'atropine ou le midazolam mais fut réduit après morphine $(P<0,01)$. La toux lors de l' induction de l'anesthésie n'est pas désirée chez certains patients, et la stimulation de la toux par le fentanyl chez des patients non-prémédiqués peut être d'une importance clinique.

One of the useful side-effects of opioid analgesics is suppression of the cough reflex, ${ }^{1}$ and is the basis of their use in oral cough suppresants. ${ }^{2}$ However, we have observed that some patients coughed after an $i v$ bolus of fentanyl. This relatively unknown effect of fentanyl has only recently been reported in the anaesthetic literature. ${ }^{3}$ A double-blind, prospective, randomized controlled trial was conducted to establish the incidence of coughing, after a peripheral $i v$ bolus of fentanyl, and the modulation of this effect with vagolytic, hypnotic and narcotic premedication.

\section{Methods}

The trial protocol was approved by our hospital's Medical Research and Ethics Committee.

This study was conducted in two parts. In the first, 100 ASA physical status I-II patients, for various surgical procedures, were randomly assigned into a trial (Group 1) and a control group (Group 2). In part two, another 150 ASA physical status I-II patients were randomly assigned into three equal pretreatment groups. Randomization was done by a random number generator, a software within the Epistat program. Exclusion criteria included history of asthma,${ }^{4}$ chronic non-productive cough, ${ }^{5}$ upper respiratory tract infection ${ }^{6}$ in the last two weeks, or smoking. Patients on angiotensin converting enzyme inhibitors were also excluded. ${ }^{7}$ All had normal intracranial pressure ${ }^{8}$ and intact globes. ${ }^{9}$ None was scheduled for head or neck surgery. ${ }^{10}$ They recieved no premedication, other than those for pre-existing, non-respiratory diseases. 
The groups were treated as follows:

Group 1 received $1.5 \mu \mathrm{g} \cdot \mathrm{kg}^{-1}$ of preservative-free fentanyl, at room temperature, as a bolus, in a peripheral running $i v$ infusion of dextrose in saline.

Group 2 received an equivalent volume of room temperature saline.

Group 3 received $0.01 \mathrm{mg} \cdot \mathrm{kg}^{-1}$ atropine $i v$, one minute before the fentanyl.

Group 4 received $0.2 \mathrm{mg} \cdot \mathrm{kg}^{-1}$ morphine $\mathrm{im}$, one hour before the fentanyl.

Group 5 received $7.5 \mathrm{mg}$ midazolam po, one hour before the fentanyl.

Heart rate (HR) and oxygen saturation $\left(\mathrm{SaO}_{2}\right)$ were continuously monitored. Blood pressure was measured before and one minute after administration of the test solution. The patients were observed for one minute for any cough, defined as "a sudden noisy expulsion of air from the lungs, usually produced to keep the airways of the lungs free of foreign matter." I

For Groups 1 and 2, the operator administering the iv solution was given an unmarked syringe containing either fentanyl or saline, prepared by a second operator. For Groups 3, 4 and 5, the operator was not aware of the type of pretreatment. The patients though aware of the type of premedication, were not aware of the nature of the trial. Informed consent was not sought as the trial was not expected to pose any risk, and knowledge of the trial might bias the patients.

Analysis of variance (ANOVA) was applied to compare the age and weight among the five groups. Fisher's exact test [FET] was applied to compare the results among groups.

\section{Results}

There were no significant changes in $\mathrm{SaO}_{2}$ or haemodynamic variables, except in the atropine pretreatment group, where HR increased $29.3 \pm 17.5 \%$. The five groups were comparable for age and body weight (Table 1). None of the 50 control patients coughed after the bolus of saline. The number that coughed within one minute of iv fentanyl were 14 (28\%) of the patients in Group 1, 15 (30\%) in Group 3, three (6\%) in Group 4 and $20(40 \%)$ in Group 5 (Table II).

TABLE I Demographic data of patients

\begin{tabular}{lll}
\hline Group & Age (yr) & Weight $(\mathrm{kg})$ \\
\hline 1 & $30.9 \pm 9.9$ & $56.3 \pm 10.7$ \\
2 & $33.4 \pm 8.8$ & $57.4 \pm 9.9$ \\
3 & $31.5 \pm 9.8$ & $54.5 \pm 9.9$ \\
4 & $34.9 \pm 10.9$ & $56.7 \pm 9.4$ \\
5 & $34.5 \pm 8.6$ & $55.2 \pm 8.5$ \\
\hline
\end{tabular}

Values are expressed as mean $\pm \mathrm{SD}$.

\section{COUGH REFLEX ARC}

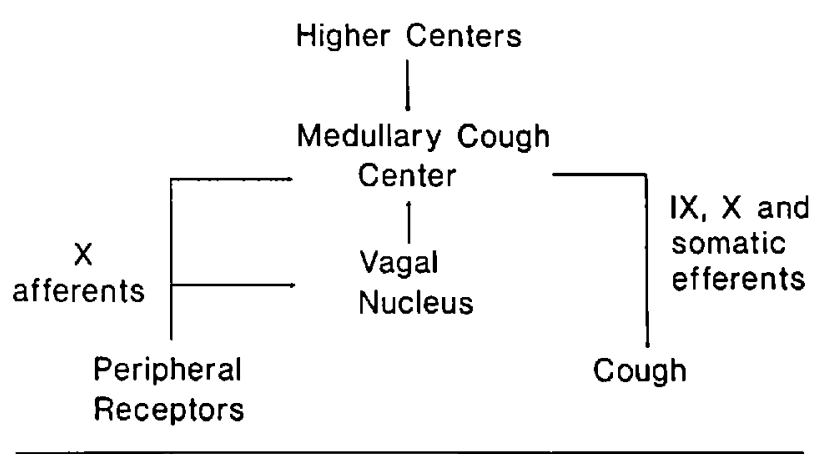

FIGURE Cough reflex arc.

Comparing Groups 1 and 2, fentanyl provoked cough in a significant proportion of patients at $P<0.0001$. Comparing each pretreatment group against Group 1, the $P$ values were not significant for Groups 3 and 5. For Group 4 the $P$ value was significant at $P<0.01$.

\section{Discussion}

Fentanyl, via a peripheral venous line, provoked cough in $28 \%$ of patients. This decreased after pretreatment with morphine, but not after vagolytic or midazolam premedication.

This contrasts with Bohrer's series ${ }^{3}$ where only $2.7 \%$ of patients given $7 \mu \mathrm{g} \cdot \mathrm{kg}^{-1}$ fentanyl via a peripheral cannula had a cough response, while $45.9 \%$ coughed after a bolus of $7 \mu \mathrm{g} \cdot \mathrm{kg}^{-1}$ through a central venous line. In that trial the patients were premedicated with $0.1 \mathrm{mg} \cdot \mathrm{kg}^{-1}$ midazolam $\mathrm{im}$. In our $7.5 \mathrm{mg}$ oral midazolam pretreatment group, the incidence of cough response was $40 \%$. The difference may be due to a dose-specific effect of fentanyl at effector sites. It could also be affected by the different routes of midazolam premedication or differences in the rate of injection of fentanyl.

The Figure is a simplified circuit of the cough reflex arc. The medullary cough centre receives afferent signals via the vagus. It also receives contributions from the vagal nucleus and higher brain stem and cortical centers.

TABLE II Results of trial

\begin{tabular}{lll}
\hline Group & $\begin{array}{l}\text { Number of putients } \\
\text { that coughed }(\%)\end{array}$ & Total $(\%)$ \\
\hline 1 & $14(28)$ & $50(100)$ \\
2 & 0 & $50(100)$ \\
3 & $15(30)$ & $50(100)$ \\
4 & $3(6)$ & $50(100)$ \\
5 & $20(40)$ & $50(100)$ \\
\hline
\end{tabular}


TABLE III Possible pathways for FCR

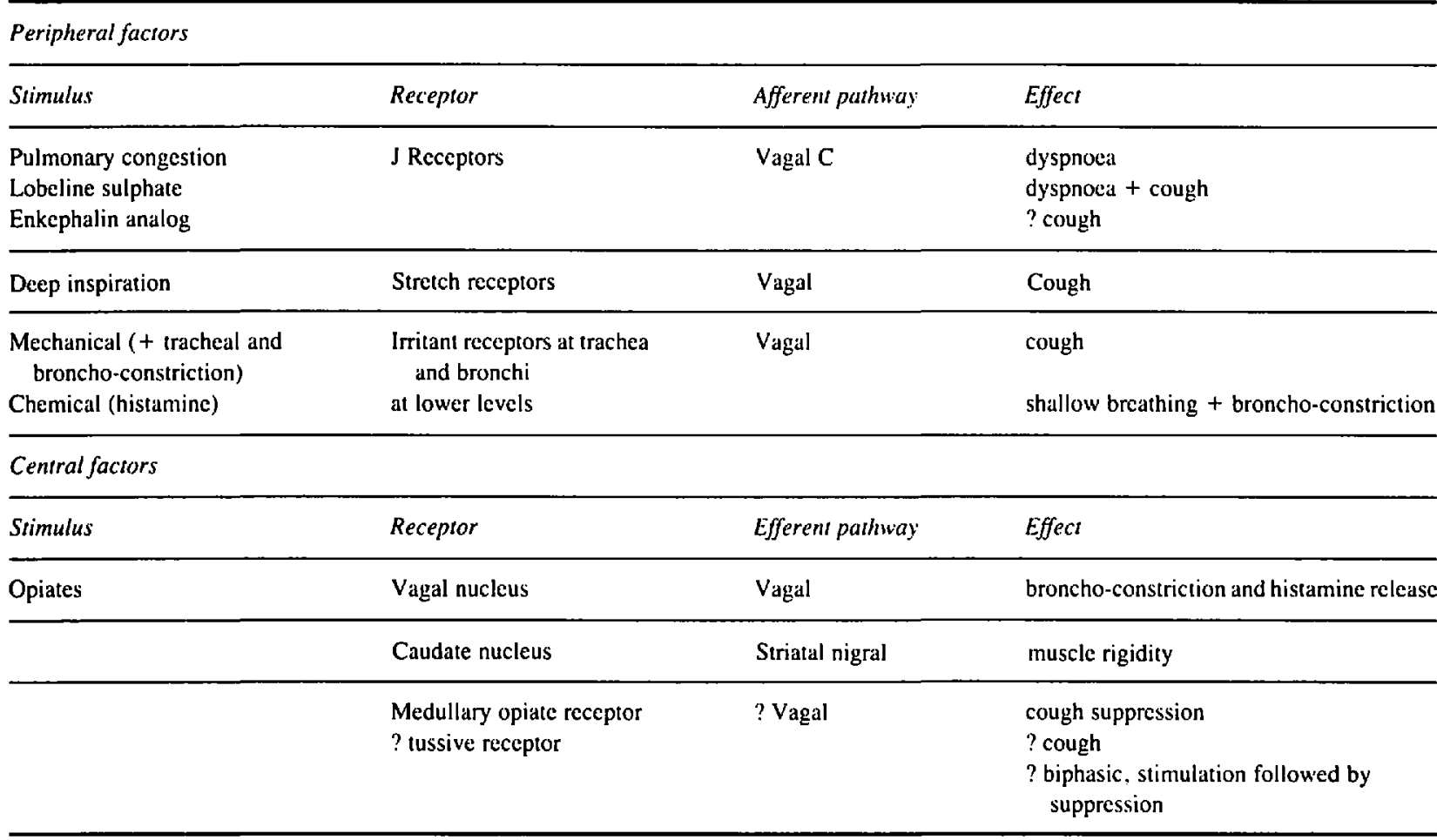

Outflow is via vagal, glossopharyngeal and somatic efferents to effect cough. For this discussion we shall term the cough provoked by fentanyl a fentanyl cough reflex (FCR). Fentanyl may provoke cough by stimulating peripheral receptors, or it may act through central receptors or pathways. The possible pathways for FCR are shown in Table III.

The natural stimulus for $\mathbf{J}$ receptors is pulmonary congestion, perceived as dyspnoea ${ }^{12}$ and can be blocked by vagotomy. ${ }^{13}$ In man the response of these receptors to lobeline sulphate is cough. ${ }^{14}$ Sapru ${ }^{15}$ found that these could be stimulated by an enkephalin-analog. Bohrer ${ }^{3}$ suggested that FCR arose as a result of $J$ receptor stimulation. Atropine, a vagolytic at muscuranic sites, did not decrease FCR, despite producing significant tachycardia. This suggests that vagal efferent pathways, acting via muscuranic receptors, may not be involved in FCR. It would be interesting to study the effects of a bolus of fentanyl in patients with vagal block, as in Guz et al.'s patients, ${ }^{13}$ or in patients who have received lung transplants.

Stretch receptors can trigger cough and bronchoconstriction upon deep inspiration, especially in asthmatics. This presumably requires inflammatory "priming" of the rapidly adapting irritant receptors. ${ }^{16}$ This is an unlikely mechanism of FCR since patients with reactive airway or inflammatory disease were excluded, and there was no airway or ventilatory manoeuvres.
Irritant receptors in the upper pulmonary mucosa are more sensitive to mechanical stimuli, while those at the lower level are triggered by chemical stimuli. ${ }^{12}$ In man, stimulation of these deeper receptors causes rapid shallow breathing and bronchoconstriction. Stimulation of the upper pulmonary receptors causes cough. Irritant receptors can also be stimulated by deformation of the mucosa, secondary to tracheal smooth muscle constriction ${ }^{17}$ or bronchoconstriction. ${ }^{18}$ As fentanyl has been reported to contract tracheal smooth muscle, ${ }^{19}$ these receptors are possible afferent sites for FCR.

Bronchomotor tone is augmented by central vagal discharge ${ }^{20}$ and fentanyl is known to stimulate the vagal nucleus. ${ }^{21}$ Histamine can also stimulate irritant receptors, either directly ${ }^{22}$ or via triggering bronchoconstriction. ${ }^{18}$ Fentanyl does not cause direct release of histamine,${ }^{23}$ but preganglionic parasympathetic stimulation has been shown to augment histamine release by mast cells. ${ }^{24}$ Vagotomy attenuated the effects of central vagal stimulation by fentanyl. ${ }^{21}$ Thus vagally mediated bronchoconstriction or histamine release is an unlikely mechanism for FCR, as incidence of cough was not affected by atropine premedication.

Sudden adduction of the vocal cords or supraglottic obstruction by soft tissues, secondary to muscle rigidity, ${ }^{25}$ may trigger a cough. The mechanism is by activation of $\mathrm{Mu}$ receptors on interneurons in the caudate nucleus, with enhanced central striatal dopamine de- 
gradation. ${ }^{26} \mathrm{GABA}$ receptor agonists and antagonists have also been applied to the substantia nigra with modulation of this narcotic-induced rigidity. ${ }^{27}$ Benzodiazepines have GABA receptor agonistic properties, ${ }^{28}$ which could modify the response of striatal-nigral pathways to a bolus of fentanyl. However, midazolam premedication did not significantly alter our incidence of FCR.

Opioids depress the cough reflex, by a direct effect on the medullary cough centre. This involves opiate receptors that are less stereospecific, and less sensitive to naloxone, than those responsible for analgesia. With several opioids, the dose required to supress cough is lower than that required for analgesia. ${ }^{1}$ Also, the degree of relief reported by patients, given codeine, does not correlate with the actual reduction of frequency of coughing. ${ }^{2}$ All this supports receptor dualism, with distinct receptors mediating the antitussive action of opioids, as opposed to those for analgesia.

In both Bohrer's ${ }^{3}$ and our studies, fentanyl was given rapidly. "Slug" pharmacokinetics will affect drug delivery, favouring well-perfused organs with high lipid content. This may deliver different concentrations of molecules to different populations of opiate receptors.

Knoll, ${ }^{29}$ found that an azidomorphine derivative stimulated some opiate receptors while inhibiting others. It is postulated here that selective distribution or dose of fentanyl may perhaps temporarily inhibit those receptors which are responsible for the antitussive property of opioids, while stimulating another unknown population of receptors, provoking FCR.

\section{Conclusion}

Fentanyl, when given through a peripheral cannula, provoked a cough response in a significant proportion of patients. This was not altered by premedication with atropine or midazolam. Opiate receptor dualism may be the factor mediating cough, or fentanyl may have a biphasic effect on opiate receptors, probably related to a specific dose range, governed by the rate of administration. Two other possible pathways for FCR, as discussed, involve stimulation of the $\mathrm{J}$ receptors or irritant receptors. The former would require relay of efferent signals independent of vagal efferent pathways acting via muscuranic receptors. The latter would be an indirect effect secondary to contraction of tracheal smooth muscle.

Coughing upon induction of anaesthesia is undesirable in patients with raised ICP or an open globe. Fentanyl at induction should be used with caution, even at doses of $1.5 \mu \mathrm{g} \cdot \mathrm{kg}^{-1}$. In these and in patients with history of reactive airways, iv fentanyl at induction of anaesthesia should perhaps be preceded by opioid premedication.

\section{References}

1 Jaffe JH, Martin WR. Opoid analgesics and antagonists. Goodman and Gillman's The Pharmacological Basis of Therapeutics. 7th ed. New York: Macmillan Publishing Company. 1985; 491-531.

2 Sevelius $H, M c C o y J F$, Colmore JP. Dose response to codeine in patients with chronic cough. Clin Pharmacol Ther 1971; 12: 449-55.

3 Bohrer $H$, Fleischer $F$, Werning $P$. Tussive effects of a fentanyl bolus administered through a central venous catheter. Anaesthesia 1990; 45: 18-21.

4 Cockcroft DW, Killian DN, Mellon JJA, Hargreave $F E$. Bronchial reactivity to inhaled histamine: a method and clinical survey. Clin Allergy 1977; 7: 235-43.

5 Fuller RW, Choudry NB. Patients with a nonproductive cough have an increased cough reflex. Thorax 1989; 255-6P.

6 Empey $D W$, Laitinen LA, Jacobs $L$, Gold WM, Nadel $J A$. Mechanisms of bronchial hyperteactivity in normal subjects after upper respiratory tract infection. Am Rev Respir Dis 1976; 113: 131-9.

7 Fuller $R W$, Choudry $N B$. Increased cough reflex associated with angiotensin converting enzyme inhibitor cough. BMJ 1987; 295: 1025-6.

8 Miller JD, Becker DP, Ward JD, Sullivan HG, Adams WE. Rosner MJ. Significance of intracranial hypertension in severc head injury. J Neurosurg 1977; 47: 503-16.

9 Giesecke $A H$, Egbert $L D$. Ancsthesia for trauma surgery. Anesthesia. 2nd ed. New York: Churchill Livingstone Inc. 1986; 1833.

10 Atkinson RS, Rushman GB, Let JA. A Synopsis of Anaesthesia, 9th ed. First PG Asian Economy Ed. Singapore: PG Publishing Pte Lid. 1984; 334.

11 Friel JP. Dorland's Illustrated Medical Dictionary, 26th ed. Igaku-Shoin/Saunders International Ed. Philadelphia: WB Saunders 1982; 312.

12 Widdicombe JG. Pulmonary and respiratory tract receptors. J Exp Biol 1982; 100: 41-57.

13 Guz A, Nobel MIM, Eisele JH, Trenchard D. Experimental results of vagal block in cardiopulmonary disease. Breathing: Hering-Breuer Centenary Symposium. London: Churchill 1970; 315-29.

14 Jain SK, Subramanian S, Julka DB, Guz A. Search for evidence of lung chemoreflexes in man: study of respiratory and circulatory effects of phenyldiguanide and lobeline. Clin Sci 1972; 42: 163-77.

15 Sapru $H N$, Willette $B N$, Krieger AJ. Stimulation of pulmonary J receptors by an enkephalin-analog. J Pharmacol Exp Ther 1981; 217: 228-34.

16 Widdicombe JG. Receptors in the trachea and bronchi of the cat. J Physiol 1954; 123; 71-104.

17 Sant'Ambrogio G, Remmers JE, De Groot WJ, Callas $G$, Mortola $J P$. Localisation of rapidly adapting receptors 
in the trachea and main stem bronchus of the dog. Respir Physiol 1978; 33: 359-66.

18 Chausow AM, Banner AS. Comparison of tussive effects of histamine and methacholine in humans. J Appl Physiol 1983; 55: 541-6.

19 Yasuda I, Hircno T, Yusa T, Satoh M. Tracheal constriction by morphine and fentanyl in man. Anesthesiology 1978; 49: 117-9.

20 Leff AR. Endogenous regulation of bronchomotor tone. Am Rev Respir Dis 1988; 137: 1198-216.

21 Reitan JA, Stengert KB, Wymore $M L$, Martucci $R W$. Central vagal control of fentanyl-induced bradycardia during halothane ancsthesia. Anesth Analg 1978; 57:31-6.

22 Vidruk EH, Hahn HL, Nadel JA, Sampson SR. Mechanisms by which histamine stimulates rapidly adapting receptors in dog lungs. J Appl Physiol 1977; 43: 397-402.

23 Hermens JM, Ebertz JM, Hanifin JM, Hirshman CA. Comparison of histamine release in human skin mast cells induced by morphinc, fentanyl and oxymorphone. Anesthesiology 1985; 62: 124-9.

24 Leff AR, Stimler NP, Munoz NM, Shioya T, Tallet J, Dame $C$. Augmentation of respiratory mast cell sccretion of histamine caused by vagus nerve stimulation during antigen challenge. J Immunol 1985; 136: 1066-73.

25 Benthuysen JL, Smith NT, Sanford TJ, Head N, Dec-Silver $H$. Physiology of alfentanil-induced rigidity. Anesthesiology 1986; 64: 440--6.

26 Wand $P$, Kuschinsky $K$, Sontag KH. Morphine-induced muscular rigidity in rats. Eur J Pharmacol 1973; 24: 189-93.

27 Havemann $U$, Turski L, Schwaz $M$, Kuschinsky $K$. On the role of GABA-ergic mechanisms in striatum and substantia nigra in mediating muscular rigidity. Naunyn Schmiedebergs Arch Pharmacol 1983; 322 (Supp): 373

28 Haefely WE. Benzodiazepines. Int Anesthesiol Clin 1988; 26: 262-72.

29 Knoll J. Two kinds of opiate receptors. Pol J Pharmacol Pharm 1977; 29: 165-75. 